\title{
Evaporation of S from Liquid Fe-C-S Alloy
}

\author{
Youn-Bae $\mathrm{KANG}^{1) *}$ and Fahmi TAFWIDLI ${ }^{1,2)}$ \\ 1) Graduate Institute of Ferrous Technology, Pohang University of Science and Technology, Pohang, 37673, Kyungbuk, Rep. \\ of Korea. \\ 2) PT. Krakatau POSCO, Cilegon, 42443, Indonesia.
}

(Received on August 18, 2017; accepted on September 8, 2017)

\begin{abstract}
Evaporation mechanism of S from liquid Fe-C-S alloys at $1873 \mathrm{~K}$ was proposed by analyzing available experimental data. It has been known that increasing $\mathrm{C}$ content in liquid alloy increases activity coefficient of $S\left(f_{s}\right)$, and it could raise driving force for the evaporation reaction $\underline{S}=S(g)$. However, experimental data of the evaporation of $\mathrm{S}$ in the $\mathrm{Fe}-\mathrm{C}-\mathrm{S}$ alloys could not be accounted for only by considering the increases of $f_{\mathrm{s}}$. In the present study, formation of carbosulfides, CS(g) and $\mathrm{CS}_{2}(\mathrm{~g})$, was additionally taken into account in order to explain role of $\mathrm{C}$ for the accelerated $\mathrm{S}$ evaporation. Surface adsorption of $\mathrm{S}$ was also taken into account, which retards the evaporation rate of S. An evaporation model equation was formulated. It can be applied to calculate the evaporation rate of $\mathrm{S}$ over wider $\mathrm{C}$ content (from zero to its saturation to liquid alloy).
\end{abstract}

KEY WORDS: evaporation; Fe-C-S; carbosulfide; surface adsorption

\section{Introduction}

Behavior of $\mathrm{S}$ in liquid iron is one of interesting behaviors of variety of chemical reactions during ironmaking and steelmaking processes. Desulfurization of liquid iron in blast furnace is carried out by lime in flux, which forms an ironmaking slag. It is known that $\mathrm{S}$ in liquid iron transfers from the liquid iron to the lime probably by forming sulfur-bearing volatile species. ${ }^{1)}$ Sulfur content in iron and various other alloys could be reduced markedly by vacuum. ${ }^{2-4)}$ This also supports that evaporation of $\mathrm{S}$ from liquid metal including iron may be an important step of desulfurization.

Recent investigations of evaporative refining of molten ferrous scrap in order to remove $\mathrm{Cu}$ and $\mathrm{Sn}$ also showed that evaporation of $\mathrm{S}$ from the molten ferrous scrap significantly influences the evaporation rate of $\mathrm{Cu}$ and Sn. Jung et al. found that $\mathrm{S}$ plays very important but opposite two roles in the evaporation of $\mathrm{Cu}$ and $\mathrm{Sn}: 1) \mathrm{S}$ is easily adsorbed onto surface of the molten ferrous scrap, thereby blocking evaporation site of $\mathrm{Cu}$ and $\mathrm{Sn}, 2) \mathrm{S}$ forms volatile species such as $\mathrm{CuS}(\mathrm{g})$ and $\mathrm{SnS}(\mathrm{g})$, thereby enhancing the evaporation of $\mathrm{Cu}$ and $\mathrm{Sn}^{5,6,8)}$ Adding $\mathrm{C}$ into molten ferrous scrap accelerates evaporation of $\mathrm{S}$, as well as $\mathrm{Cu}$ and $\mathrm{Sn}^{\left.7{ }^{79}\right)}$ However, $\mathrm{C}$ competes with $\mathrm{Cu}$ and $\mathrm{Sn}$ in order to take S. Jung et al. proposed that $\mathrm{C}$ and $\mathrm{S}$ react to form $\mathrm{CS}_{2}(\mathrm{~g})$ species in $\mathrm{C}$ saturated molten ferrous scrap, which is basically $\mathrm{Fe}-\mathrm{C}-\mathrm{S}$ alloys with $\mathrm{Cu}$ and $\mathrm{Sn}^{8,9)}$ In order to precisely know the evaporation rate of $\mathrm{Cu}$ and $\mathrm{Sn}$ from liquid $\mathrm{Fe}-\mathrm{C}-\mathrm{S}$ alloys, it is prerequisite to understand evaporation of $\mathrm{S}$ in liquid $\mathrm{Fe}-\mathrm{C}-\mathrm{S}$ alloys. Jung et al. investigated the evaporation of $\mathrm{S}$

\footnotetext{
* Corresponding author: E-mail: ybkang@postech.ac.kr DOI: http://dx.doi.org/10.2355/isijinternational.ISIJINT-2017-498
}

in liquid $\mathrm{Fe}-\mathrm{C}-\mathrm{S}$ alloys at $1873 \mathrm{~K}$ of various $\mathrm{S}$ content, but only $\mathrm{C}$ saturated condition. ${ }^{7)}$ They also developed a kinetic model equation for $\mathrm{S}$ evaporation, but it was only limited to $\mathrm{Fe}-\mathrm{C}-\mathrm{S}$ alloy at $\mathrm{C}$ saturation. ${ }^{7)}$

Almost at the same time, another interesting investigation was carried out by Wu et al. ${ }^{10)}$ They investigated evaporation of $\mathrm{S}$ in liquid $\mathrm{Fe}-\mathrm{C}-\mathrm{S}$ alloys at $1873 \mathrm{~K}$ of various $\mathrm{C}$ content, at approximately similar $\mathrm{S}$ content $\left([\text { pct } \mathrm{S}]_{0}=\right.$ $0.1-0.14)$. Both studies ${ }^{7,10)}$ employed very similar technique (electromagnetic levitation under flowing $\mathrm{Ar}$ gas of the same flow rate). Therefore, these two independent investigations may be used in order to understand evaporation mechanism of $\mathrm{S}$ in liquid $\mathrm{Fe}-\mathrm{C}-\mathrm{S}$ alloys of various $\mathrm{C}$ and $\mathrm{S}$ content, at least at $1873 \mathrm{~K}$. In the present article, these two experimental research results were carefully analyzed in order to develop a model equation for $\mathrm{S}$ evaporation in liquid $\mathrm{Fe}-\mathrm{C}-\mathrm{S}$ alloys. Concentration unit used throughout this manuscript is mass percent.

\section{Previous Studies}

Sehgal and Michell investigated kinetics of desulfurization of steel. ${ }^{11)}$ They measured content of S in liquid Fe-C-S alloy at $1853 \mathrm{~K}$ under vacuum. They found that increasing $\mathrm{C}$ content increased evaporation rate of $\mathrm{S}$. Increasing 1 mass pct. of $\mathrm{C}$ (from 0.13 pct. to 1.30 pct.) increased apparent rate constant of $\mathrm{S}$ evaporation $\left(m_{\mathrm{S}}\right) 1.4$ times. This value was coincident with a value $f_{\mathrm{S}}^{\mathrm{C}}(=1.4)$, increase of the activity coefficient of $\mathrm{S}$ by $\mathrm{C}{ }^{12)}$ Therefore, they concluded that the increase of evaporation of $\mathrm{S}$ by $\mathrm{C}$ was due to the increase of activity coefficient of $\mathrm{S}$ in the liquid alloy.

Fruehan and Turkdogan also investigated kinetics of desulfurization under vacuum ${ }^{1)}$ at various temperatures (1 $553 \mathrm{~K}, 1773 \mathrm{~K}, 1873 \mathrm{~K})$. They reported that the evapo- 
ration rate was significantly lower than free evaporation of $\mathrm{S}$ under vacuum. They considered surface adsorption of $\mathrm{S}$ on the kinetics of $\mathrm{S}$ evaporation. They also observed that increasing $\mathrm{C}$ content in liquid $\mathrm{Fe}-\mathrm{C}-\mathrm{S}$ alloys increased evaporation rate of $\mathrm{S}$, but the rate was still lower than that of free evaporation. They concluded that role of $\mathrm{C}$ was increasing activity coefficient of $\mathrm{S}\left(f_{\mathrm{S}}\right)$, as was proposed by Sehgal and Michell. ${ }^{11)}$ Although they were aware of the presence of carbosulfide gas species, they concluded that neither $\mathrm{CS}(\mathrm{g})$ nor $\mathrm{CS}_{2}(\mathrm{~g})$ had formed in their experiment.

Later, the experimental data of Fruehan and Turkdogan ${ }^{1)}$ were reanalyzed by Belton with Fruehan and Turkdogan. ${ }^{13)}$ Belton pointed out that Fruehan and Turkdogan employed an inaccurate value for the Gibbs energy of dissociate of $\mathrm{S}_{2}(\mathrm{~g})$ to $2 \mathrm{~S}(\mathrm{~g})$ from Elliott and Gleiser, ${ }^{14)}$ subsequently for the Gibbs energy of $\underline{S}=\mathrm{S}(\mathrm{g})$. Belton reported that use of the inaccurate Gibbs energy resulted in significantly high evaporation rate in the calculation of Fruehan and Turkdogan. ${ }^{1)}$ Taking more accurate Gibbs energy values resulted in an interesting finding that evaporation rate of $\mathrm{S}$ in $\mathrm{Fe}-\mathrm{C}-\mathrm{S}$ alloys was even faster than a calculated rate based on Langmuir equation for free evaporation. ${ }^{16)}$ Belton concluded that the free evaporation of $\mathrm{S}$ cannot explain the data of Fruehan and Turkdogan, and evaporation of carbosulfides gas species cannot be neglected. He did not consider surface adsorption of $\mathrm{S}$.

Wu et al. employed an electromagnetic levitation technique to carry out a series of gas-liquid reaction at 1 bar pressure. ${ }^{10)}$ A number of $\mathrm{Fe}-\mathrm{C}-\mathrm{S}$ alloys of various $\mathrm{C}$ content were prepared. Each of these alloys were then levitated, and $\mathrm{S}$ was allowed to evaporate. The evaporation could be explained by a first order reaction rate,

$$
\frac{d[\text { pct } \mathrm{S}]}{d t}=-\frac{A}{V} m_{\mathrm{S}}[\text { pct } \mathrm{S}]
$$

where $t, A, V$, and $[\mathrm{pct} \mathrm{S}]$ are reaction time (sec), surface area $\left(\mathrm{m}^{2}\right)$, volume $\left(\mathrm{m}^{3}\right)$, mass percent of $\mathrm{S}$ at time $t$, respectively. Assuming $A, V$, and $m_{\mathrm{S}}$ not being dependent on [pct S], the Eq. (1) can be integrated into:

$$
\ln \frac{[\text { pct } \mathrm{S}]}{[\text { pct } \mathrm{S}]_{0}}=-\frac{A}{V} m_{\mathrm{S}} t
$$

where $[\text { pct } S]_{0}$ is an initial $\mathrm{S}$ content. The rate constant $m_{\mathrm{S}}$ obtained by fitting their experimental data was not a constant. They confirmed that increasing $\mathrm{C}$ content increased evaporation rate of $\mathrm{S}$ : $m_{\mathrm{S}}$ increased as [pct C] increased. They first tried to explain the increase of $m_{\mathrm{S}}$ by an increase of $f_{\mathrm{S}}$ by $\mathrm{C}$ content:

$$
\log f_{\mathrm{S}}=e_{\mathrm{S}}^{\mathrm{C}}[\mathrm{pct} \mathrm{C}]+r_{\mathrm{S}}^{\mathrm{C}}[\mathrm{pct} \mathrm{C}]^{2}
$$

where the first order interaction parameter $e_{\mathrm{S}}^{\mathrm{C}}(=0.11)$ and second order interaction parameter $r_{S}^{C}(=0.0058)$ both at $1873 \mathrm{~K}$ were taken from References 16. If the increased evaporation rate of $\mathrm{S}$ was only due to effect of the increase of $f_{\mathrm{S}}$, then, the plot of $\ln [$ pct $S] /[\text { pct } S]_{0}$ with respect to $f_{\mathrm{S}} \times(A / V) t$ should yield a straight line, regardless of $\mathrm{C}$ content in the alloy:

$$
\ln \frac{[\text { pct } \mathrm{S}]}{[\text { pct } \mathrm{S}]_{0}}=-f_{\mathrm{S}} \frac{A}{V} m_{\mathrm{S}}{ }^{\prime} t
$$

where $m_{\mathrm{S}}{ }^{\prime}$ is a modified apparent rate constant (m $\mathrm{sec}^{-1}$ ). Nevertheless, their experimental data were not still explained by the Eq. (4): $m_{\mathrm{S}}{ }^{\prime}$ still increased as C content increased. Therefore, it was clear that the faster evaporation rate was not solely accounted for by the increase of $f_{\mathrm{S}}$ by C. In any respect, $\mathrm{Wu}$ et al. postulated that the interaction parameters used in the calculation might be inaccurate. They utilized their experimental data in order to extract the interaction parameters, assuming equilibrium was achieved in their experiment. Newly derived interaction parameters were 0.113 for $e_{\mathrm{S}}^{\mathrm{C}}$ and 0.028 for $r_{\mathrm{S}}^{\mathrm{C}}$ at $1873 \mathrm{~K}$, respectively. Inserting these new interaction parameters into the Eq. (3), and subsequently in the Eq. (4), they could obtain a single straight linear plot of $\ln [$ pct $S] /[\text { pct } S]_{0}$ with respect to $f_{\mathrm{S}} \times(A / V) t$. However, these interaction parameters are thought to be less reliable. First, their experimental procedure was a typical of kinetic investigation for the heterogeneous gas-liquid reaction. Equilibrium should not be assumed for obtaining solution thermodynamics of the liquid phase. Second, the newly proposed interaction parameters are not consistent with well-known thermodynamics of the liquid $\mathrm{Fe}-\mathrm{C}-\mathrm{S}$ system. Most recent thermodynamic analysis of the $\mathrm{Fe}-\mathrm{C}-\mathrm{S}$ system using CALPHAD method showed that $e_{\mathrm{S}}^{\mathrm{C}}$ and $r_{\mathrm{S}}^{\mathrm{C}}$ at $1873 \mathrm{~K}$ are 0.0926 and 0.00938 , respectively. ${ }^{17)}$ These values are significantly different to what $\mathrm{Wu}$ et al. derived from their kinetic data. Therefore, it is thought that the interaction parameters proposed by $\mathrm{Wu}$ et al. are not thermodynamically appropriate values, and more importantly, the Eq. (4) does not properly represent the evaporation of $\mathrm{S}$ from liquid $\mathrm{Fe}-\mathrm{C}-\mathrm{S}$.

Jung et al. carried out a series of experiment using the electromagnetic levitation technique. ${ }^{7)}$ They measured evaporation rate of $\mathrm{S}$ in $\mathrm{Fe}-\mathrm{S}$ alloy and $\mathrm{C}$ saturated $\mathrm{Fe}-\mathrm{C}-\mathrm{S}$ alloy at $1873 \mathrm{~K}$. They showed that faster evaporation rate at $\mathrm{C}$ saturated alloy could not be solely explained by the increase of $f_{\mathrm{s}}$. According to the report of Kato and Fukube, some of carbosulfide gas species should be responsible. ${ }^{18)}$ They analyzed their experimental data of the $\mathrm{C}$ saturated alloy assuming either evaporation of $\mathrm{CS}(\mathrm{g})$ or evaporation of $\mathrm{CS}_{2}(\mathrm{~g})$. They found that consideration of $\mathrm{CS}_{2}(\mathrm{~g})$ as the evaporating species could explain the faster evaporation rate of S, with well-known thermodynamic information (interaction parameters). This looks consistent with the conclusion of Belton et al. ${ }^{13)}$ Jung et al. also took into account the effect of surface adsorption of $\mathrm{S}$, as was done for kinetic analysis of evaporation of $\mathrm{Sn}$ and $\mathrm{Cu}$ from liquid iron containing S. ${ }^{5-9)}$ However, their model was valid only at $\mathrm{C}$ saturation condition.

\section{Model for Evaporation Rate of $\mathrm{S}$ from Liquid $\mathrm{Fe}-\mathrm{C}-\mathrm{S}$ Alloy}

As was shown in the previous works, the evaporation of $\mathrm{S}$ from liquid $\mathrm{Fe}-\mathrm{C}-\mathrm{S}$ alloy should be considered with the followings: 1) increasing $f_{\mathrm{S}}$ by $\mathrm{C}$ (Eq. (3)) should be responsible for faster evaporation of $\mathrm{S}$ from $\mathrm{Fe}-\mathrm{C}-\mathrm{S}$ alloy, but this is insufficient to fully explain the faster evaporation, 2) certain amount of carbosulfide gas species should be responsible for the faster evaporation, 3 ) evaporating species may vary depending on $\mathrm{C}$ and $\mathrm{S}$ contents in the liquid alloy.

As reported by many investigators, $\mathrm{S}$ evaporation from 
$\mathrm{Fe}-\mathrm{C}-\mathrm{S}$ alloys can be in form of solely $\mathrm{S}(\mathrm{g})$ or another $\mathrm{S}$ gas compound such as $\mathrm{CS}$ or $\mathrm{CS}_{2}{ }^{1,13,18-20)}$ Kato and Fukube reported that during vacuum melting of $\mathrm{Fe}-\mathrm{C}-\mathrm{S}$ alloys at temperature range of $1273 \mathrm{~K}-1673 \mathrm{~K}$, the ions $\mathrm{S}^{+}, \mathrm{S}_{2}{ }^{+}$, $\mathrm{CS}^{+}$, and $\mathrm{CS}_{2}{ }^{+}$were found from the mass spectrometry. ${ }^{18)}$ Fruehan and Turkdogan also suggested that $\mathrm{S}$ may evaporate as $\mathrm{S}(\mathrm{g})$ and $\mathrm{S}$-containing gas compound. ${ }^{1)}$ In order to check thermodynamic stability of various $\mathrm{S}$ containing gas species, a thermodynamic calculation was carried out using FactSage $^{21,22)}$ with FactPS database for gas components and a database recently developed by the present authors for liquid alloy. ${ }^{17)}$ Figure 1 shows partial pressure of various gas species in equilibrium with liquid Fe-S-C alloys at 1873 $\mathrm{K}$. [pet S] was set to 0.1 and [pct $\mathrm{C}$ ] was varied from 0 to 5. As can be seen in the figure, partial pressure of these gas species increases as [pct C] increases. When [pct C] $>0.8$, partial pressure $\mathrm{CS}(\mathrm{g})$ is dominant over that of $\mathrm{S}(\mathrm{g})$ or $\mathrm{S}_{2}(\mathrm{~g})$. Partial pressure of $\mathrm{CS}_{2}(\mathrm{~s})$ is also high at high $\mathrm{C}$ content, but it is not as high as that of $\mathrm{CS}(\mathrm{g})$. According to the kinetic analysis by Jung et al. for C saturated alloy, ${ }^{7}$ major evaporating species should be $\mathrm{CS}_{2}(\mathrm{~g})$, not $\mathrm{CS}(\mathrm{g})$. This discrepancy may be attributed to incompatible situation between thermodynamic equilibrium and non-equilibrium during evaporation. Nevertheless, it is wise to consider that these carbosulfide species are necessary to interpret evaporation kinetics of $\mathrm{S}$ from $\mathrm{C}$ containing liquid iron.

Therefore, it was decided to consider $\mathrm{S}(\mathrm{g}), \mathrm{CS}(\mathrm{g})$ and $\mathrm{CS}_{2}$ (g) as evaporating species:

$$
\begin{aligned}
\underline{\mathrm{S}} & =\mathrm{S}(\mathrm{g}) \\
\underline{\mathrm{C}}+\underline{\mathrm{S}} & =\mathrm{CS}(\mathrm{g}) . \\
\underline{\mathrm{C}}+2 \underline{\mathrm{S}} & =\mathrm{CS}_{2}(\mathrm{~g})
\end{aligned}
$$

Evaporation of $\mathrm{S}_{2}(\mathrm{~g})$ was not explicitly considered, but its contribution to change of $\mathrm{S}$ content in liquid alloy may be assumed to be represented by $\mathrm{S}(\mathrm{g})$. This is because 1) explicit consideration of the $\mathrm{S}_{2}(\mathrm{~g})$ induces an additional complexity in the rate equation (Eq. (8)) and requires one more rate constant to be evaluated, for example, $k_{\mathrm{S} 2}$, and 2 ) nevertheless, it only influences [pct $\mathrm{S}$ ] as the evaporation of $\mathrm{S}(\mathrm{g})$ does, not [pct $\mathrm{C}]$ as $\mathrm{CS}(\mathrm{g})$ and $\mathrm{CS}_{2}(\mathrm{~g})$ do.

The rate equation is formulated as:

$$
\begin{aligned}
\frac{d[\% \mathrm{~S}]}{d t} & =-\frac{A}{V}\left(k_{\mathrm{S}} f_{\mathrm{S}}[\text { pct S }]+k_{\mathrm{CS}} f_{\mathrm{C}}[\text { pct C }] f_{\mathrm{S}}[\text { pct S }]\right. \\
& \left.+k_{\mathrm{CS}_{2}} f_{\mathrm{C}}[\text { pct C }]\left(f_{\mathrm{S}}[\text { pct S }]\right)^{2}\right)=-\frac{A}{V} m_{\mathrm{S}}[\text { pct } \mathrm{S}]
\end{aligned}
$$

where $k_{i}$ is an apparent rate constant for individual evaporating species $i\left(i=\mathrm{S}, \mathrm{CS}, \mathrm{CS}_{2}\right)$. The apparent rate constant is formulated according to Jung et al. $(8)^{1}$ :

$$
\begin{gathered}
k_{\mathrm{S}}=\frac{k_{\mathrm{S}}^{\mathrm{R}}}{1+K_{\mathrm{S}} f_{\mathrm{S}}[\text { pct S }]} \cdots \cdots \cdots \\
k_{\mathrm{CS}}=\frac{\rho}{100 M_{\mathrm{C}}}\left(\frac{k_{\mathrm{CS}}^{\mathrm{R}}}{1+K_{\mathrm{S}} f_{\mathrm{S}}[\text { pct S }]}\right)
\end{gathered}
$$

$$
k_{\mathrm{CS}_{2}}=\frac{\rho^{2}}{10000 M_{\mathrm{C}} M_{\mathrm{S}}}\left(\frac{k_{\mathrm{CS}_{2}}^{\mathrm{R}}}{1+K_{\mathrm{S}} f_{\mathrm{S}}[\text { pct S }]}\right) \ldots \ldots \ldots
$$

where $k_{i}^{\mathrm{R}}, K_{\mathrm{S}}, M_{i}$, and $\rho$ are the chemical reaction rate constant (m sec ${ }^{-1}$ for $i=\mathrm{S}, \mathrm{m}^{4} \mathrm{~mol}^{-1} \mathrm{sec}^{-1}$ for $i=\mathrm{CS}, \mathrm{m}^{7}$ $\mathrm{mol}^{-2} \mathrm{sec}^{-1}$ for $i=\mathrm{CS}_{2}$ ), adsorption coefficient of $\mathrm{S}(-)$, and molecular weight of $i(i=\mathrm{C}, \mathrm{S})\left(\mathrm{kg} \mathrm{mol}^{-1}\right)$, and density of liquid alloy $\left(\mathrm{kg} \mathrm{m}^{-3}\right)$, respectively. The Eqs. (9) to (11) were formulated so as to take into account surface adsorption of $\mathrm{S}$ by Langmuir's ideal adsorption. ${ }^{15)} \rho$ of liquid $\mathrm{Fe}-\mathrm{C}-\mathrm{S}$ alloys at $1873 \mathrm{~K}$ was estimated from Jimbo and Cramb:23)

$$
\rho=7059-68.8 \times[\mathrm{pct} \mathrm{C}]\left(\mathrm{kg} \mathrm{m}^{-3}\right)
$$

$f_{\mathrm{S}}$ and $f_{\mathrm{C}}$ were calculated using the Eqs. (3) and (13):

$$
\log f_{\mathrm{C}}=e_{\mathrm{C}}^{\mathrm{C}}[\text { pct C }]+r_{\mathrm{C}}^{\mathrm{C}}[\text { pet C }]^{2}
$$

along with $e_{\mathrm{S}}^{\mathrm{C}}=0.0926, r_{\mathrm{S}}^{\mathrm{C}}=0.00938, e_{\mathrm{C}}^{\mathrm{C}}=0.0979, r_{\mathrm{C}}^{\mathrm{C}}=$ 0.0077 at $1873 \mathrm{~K}$, respectively. ${ }^{17)}$ Effect of $\mathrm{S}$ on the activity coefficients and density were ignored because content of $\mathrm{S}$ considered in the present study is low. $K_{\mathrm{S}}(=40$ at $1873 \mathrm{~K})$ was taken from Sekino et al., ${ }^{24)}$ which is close agreement with a report by Harashima et al. ${ }^{25)}$ and Nagasaka and Fruehan. ${ }^{26)}$ The chemical rate constants $k_{\mathrm{S}}^{\mathrm{R}}, k_{\mathrm{CS}}^{\mathrm{R}}$, and $k_{\mathrm{CS} 2}^{\mathrm{R}}$ were obtained in order to reproduce known experimental data as close as possible, which will be shown in Sec. 4 .

Once the chemical rate constants were obtained, these were inserted into Eqs. (9) to (11) with $K_{\mathrm{S}}, f_{\mathrm{S}}, f_{\mathrm{C}}, \rho$, and molecular weights $M_{\mathrm{C}}$ and $M_{\mathrm{S}}$. At a given [pct S], the apparent rate constants were obtained. By inserting these constants into the Eq. (8), the evaporation rate of $\mathrm{S}$ can be calculated. By setting a small time step $(\Delta t)$, [pct S] after $\Delta t$ can be calculated, and this is substituted back into the Eqs. (9) to (11) in order to update the apparent rate constants after $\Delta t$. These steps are then repeated up to desired time.

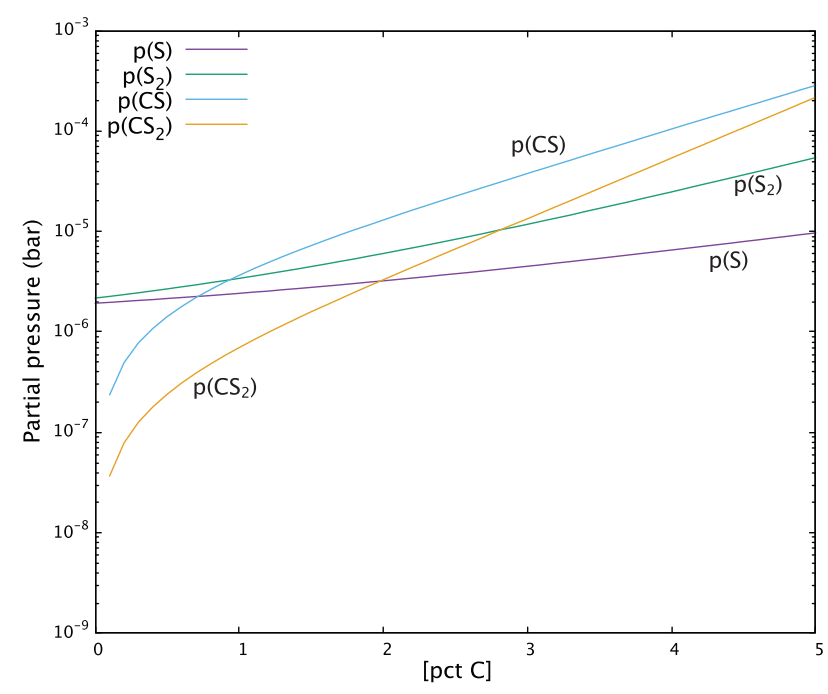

Fig. 1. Equilibrium partial pressure of various species over liquid Fe-0.5S- $(0-5) \mathrm{C}$ at $1873 \mathrm{~K}$. Equilibrium calculations were carried out using FactSage with FactPS database for gas phase and with a thermodynamic description by Tafwidli and Kang for liquid alloy. ${ }^{17)}$ (Online version in color.)

\footnotetext{
${ }^{1}$ From the formulae of Eqs. (9) to (11), it can be seen that the apparent rate constants are not really constants, but vary with temperature and composition. Nevertheless, these are referred to as constants throughout this article, in order to keep traditional name used in this type of rate equation.
} 


\section{Results}

Change of $\mathrm{S}$ content in $\mathrm{C}$ saturated liquid $\mathrm{Fe}-\mathrm{C}-\mathrm{S}$ alloys of various [pct $\mathrm{S}]_{0}$ was measured at $1873 \mathrm{~K}$ by Jung et al. ${ }^{7)}$ and it is shown in Fig. 2(a) by symbols $\left(A / V=1096 \mathrm{~m}^{-1}\right)$. In the previous study by Jung et al., ${ }^{7)}$ these data were analyzed by assuming only $\mathrm{CS}_{2}(\mathrm{~g})$ as the evaporating species. In the present study, apart from $\mathrm{CS}_{2}(\mathrm{~g}), \mathrm{CS}(\mathrm{g})$ and $\mathrm{S}(\mathrm{g})$ were also considered. Nevertheless, for the $\mathrm{C}$ saturation condition, $\mathrm{CS}_{2}$ (g) was found to be a major evaporating species at early stage of evaporation. Therefore, $k_{\mathrm{CS}_{2}}^{\mathrm{R}}$ was first fitted to the data at the early stage, then $k_{\mathrm{S}}^{\mathrm{R}}$ and $k_{\mathrm{CS}}^{\mathrm{R}}$ were fitted to the rest of data. These fitting was a first rough estimation. $k_{S}^{R}$ was also estimated by fitting reported data of $\mathrm{S}$ evaporation in $\mathrm{Fe}-\mathrm{S}$ alloy, which was reported by Jung et al. ${ }^{7)}$

After then, data of $\mathrm{Wu}$ et al. of various [pct C] $]_{0}$ were considered $\left(A / V=1042 \mathrm{~m}^{-1}\right) .{ }^{10)}$ However, during the evaluation of their work, it was found that two experimental data set from $\mathrm{Wu}$ et $a l .{ }^{10)}$ and Jung et $a l^{7)}$ were not consistent each other. Figure 3 shows the reported experimental data from these two studies for similar $\mathrm{C}$ content (4.80 to 5.06). Data of $\mathrm{Wu}$ et al. at $[\mathrm{pct} \mathrm{S}]_{0}=0.1$ showed faster decrease in [pet S] than that of Jung et al. at [pct S $]_{0}=0.068$. This tendency is not in consistent with that shown in Fig. 2(a), where higher [pct $\mathrm{S}]_{0}$ resulted in higher [pct S] at any time $t$ for samples of similar [pct C]. Reason of this discrepancy is not clear at present, although these two experimental investigations were performed under very similar conditions (electromagnetic levitation, under Ar gas of 1 liter min $^{-1}$ flow rate, $1873 \mathrm{~K}$ ). Therefore, it was not easy to directly use the data of $\mathrm{Wu}$ et al., and it was decided to take only dependency of the evaporation rate on $\mathrm{C}$ content. This was done by normalizing overall apparent rate constant $m_{\mathrm{S}}$ in Eq. (1) by $m_{\mathrm{S}}$ at nearly zero $\mathrm{C}$ content $\left(m_{\mathrm{S}}^{0}\right)$. Figure 4 shows the normalized overall rate constant $\left(m_{\mathrm{S}} / m_{\mathrm{S}}^{0}\right)$ of $\mathrm{Wu}$ et $a{ }^{10)}$ (open symbols). It can be seen that increasing [pct C] significantly increases the overall apparent rate constant $m_{\mathrm{S}}$. According to the Eq. (8), the overall rate constant and normalized overall rate constant can also be derived as:
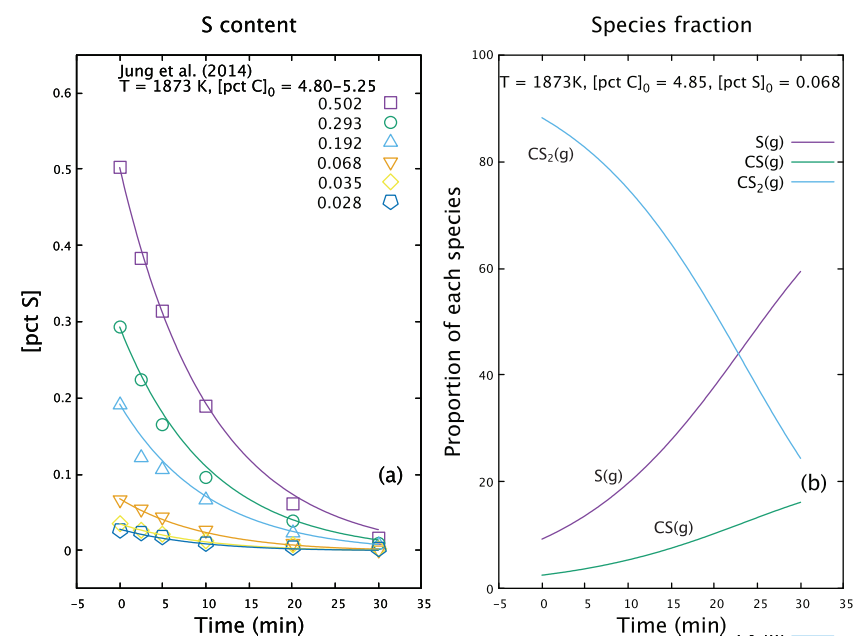

Fig. 2. (a) Change of $\mathrm{S}$ content in $\mathrm{Fe}-(4.80-5.25) \mathrm{C}-(0.028-0.502) \mathrm{S}$ at $1873 \mathrm{~K}$. Symbols represent experimental data by Jung et ll. $^{7)}$ and lines are calculated results using the Eq. (8) with the Eqs. (9)-(11). (b) Proportions of species evaporating from liquid Fe-4.85C-0.068S at $1873 \mathrm{~K}$. (Online version in color.)

$$
m_{\mathrm{S}}=k_{\mathrm{S}} f_{\mathrm{S}}+k_{\mathrm{CS}} f_{\mathrm{C}}[\mathrm{pct} \mathrm{C}] f_{\mathrm{S}}+k_{\mathrm{CS}_{2}} f_{\mathrm{C}}[\mathrm{pct} \mathrm{C}] f_{\mathrm{S}}^{2}[\mathrm{pct} \mathrm{S}] \ldots
$$

By setting $[$ pct $\mathrm{C}]=0$,

$$
m_{\mathrm{S}}^{0}=k_{\mathrm{S}} f_{\mathrm{S}}
$$

$$
\frac{m_{\mathrm{S}}}{m_{\mathrm{S}}^{0}}=1+\frac{k_{\mathrm{CS}}}{k_{\mathrm{S}}} f_{\mathrm{C}}[\mathrm{pct} \mathrm{C}]+\frac{k_{\mathrm{CS}_{2}}}{k_{\mathrm{S}}} f_{\mathrm{C}} f_{\mathrm{S}}[\text { pct C }][\mathrm{pct} \mathrm{S}] \ldots
$$

By inserting Eqs. (10) and (11) into Eq. (16), the normalized overall rate constant can be expressed as:

$$
\begin{aligned}
\frac{m_{\mathrm{S}}}{m_{\mathrm{S}}^{0}}= & 1+\frac{k_{\mathrm{CS}}^{\mathrm{R}}}{k_{\mathrm{S}}^{\mathrm{R}}} \frac{\rho}{100 M_{\mathrm{C}}} f_{\mathrm{C}}[\text { pct C }] \\
& +\frac{k_{\mathrm{C} S_{2}}^{\mathrm{R}}}{k_{\mathrm{S}}^{\mathrm{R}}} \frac{\rho^{2}}{10000 M_{\mathrm{C}} M_{\mathrm{S}}} f_{\mathrm{C}} f_{\mathrm{S}}[\text { pct C }][\text { pct S }]
\end{aligned}
$$

The $m_{\mathrm{S}} / m_{\mathrm{S}}^{0}$ may be seen to be a linear function of [pct C]. Since $\rho, f_{\mathrm{C}}$, and $f_{\mathrm{S}}$ are also dependent on [pct C], however, the $m_{\mathrm{S}} / m_{\mathrm{S}}^{0}$ does not vary linearly as [pct C]

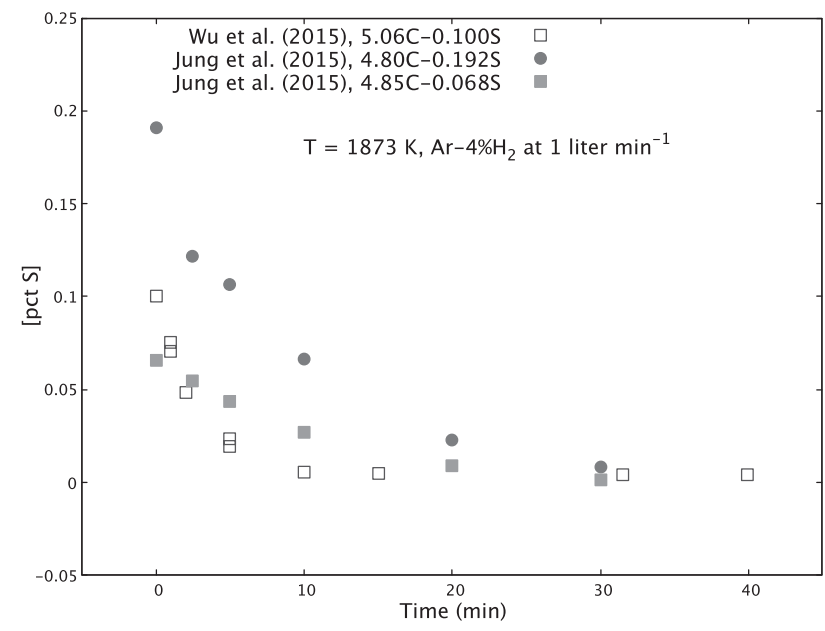

Fig. 3. Comparison between experimental results of S evaporation from two different investigations. ${ }^{710)} \mathrm{C}$ content in both studies were not much different, evaporation rate of $\mathrm{S}$ in the study of Wu et al. ${ }^{10)}$ looks faster than that of Jung et al. ${ }^{7)}$

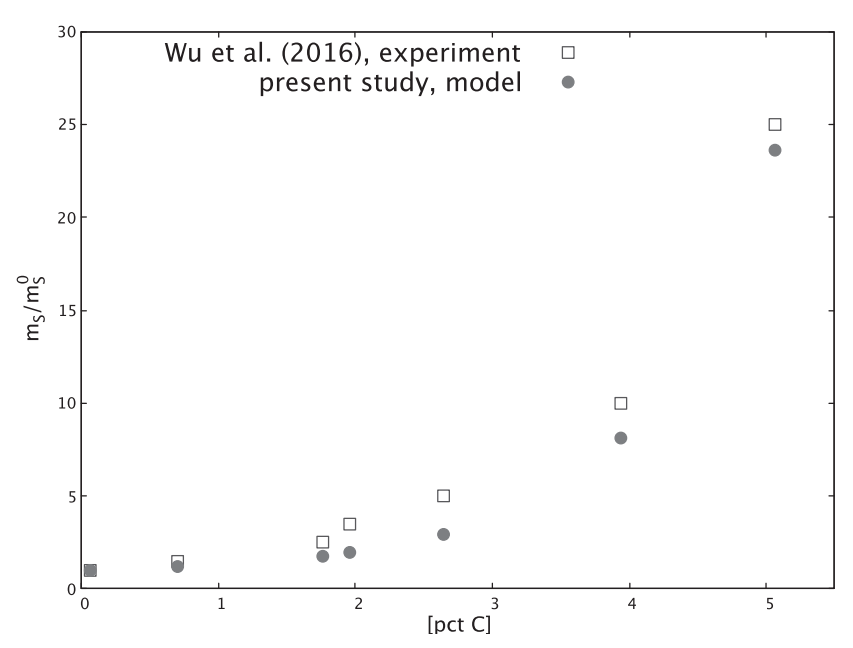

Fig. 4. Normalized apparent rate constant $\left(m_{\mathrm{S}} / m_{\mathrm{S}}^{0}\right)$ at various $\mathrm{C}$ content. Open squares are calculated from the experimental data of $\mathrm{Wu}$ et al., ${ }^{10)}$ and closed circles are calculated from the present kinetic model. 
increases. By using the data of Wu et al. shown in Fig. 4, the $k_{\mathrm{CS}}^{\mathrm{R}}$ and $k_{\mathrm{CS}_{2}}^{\mathrm{R}}$ were further optimized in order to simultaneously reproduce the experimental data shown in Figs. 2(a) and 4. The optimized rate constants are listed in Table $\mathbf{1 .}$ The calculated $m_{\mathrm{S}} / m_{\mathrm{S}}^{0}$ are shown by closed symbols in the Fig. 4. As can be seen in the figure, the calculated $m_{\mathrm{S}} / m_{\mathrm{S}}^{0}$ values are in favorable agreement with those reported by $\mathrm{Wu}$ et al. ${ }^{10)}$ Therefore, it can be concluded that the present kinetic model for $\mathrm{S}$ evaporation in liquid $\mathrm{Fe}-\mathrm{C}-\mathrm{S}$ alloy is able to represent the effect of $\mathrm{C}$ on the $\mathrm{S}$ evaporation.

It can be seen in Eq. (14) that $m_{\mathrm{S}}$ depends both on [pct C] and [pct S]. Therefore, during evaporation of $\mathrm{S}$, the $m_{\mathrm{S}}$ is not kept to be a constant. Nevertheless, it was observed in the present calculation that the $m_{\mathrm{S}}$ values did not vary much by the evaporation of S, which will be shown in Sec. 5 .

Table 1. Parameters and data used in the present study at $1873 \mathrm{~K}$.

\begin{tabular}{cccc}
\hline & Value & Unit & Reference \\
\hline$k_{\mathrm{S}}^{\mathrm{R}}$ & $4.5 \times 10^{-7}$ & $\mathrm{~m} \mathrm{sec}^{-1}$ & Present study \\
$k_{\mathrm{CS}}^{\mathrm{R}}$ & $1.0 \times 10^{-12}$ & $\mathrm{~m}^{4} \mathrm{~mol}^{-1} \mathrm{sec}^{-1}$ & Present study \\
$k_{\mathrm{CS} S_{2}}^{\mathrm{R}}$ & $5.2 \times 10^{-14}$ & $\mathrm{~m}^{7} \mathrm{~mol}^{-2} \mathrm{sec}^{-1}$ & Present study \\
$\rho$ & $7059-68.8[\mathrm{pct} \mathrm{C}]$ & $\mathrm{kg} \mathrm{m}^{-3}$ & $23)$ \\
$e_{\mathrm{S}}^{\mathrm{C}}$ & 0.0926 & - & $17)$ \\
$r_{\mathrm{S}}^{\mathrm{C}}$ & 0.00938 & - & $17)$ \\
$K_{\mathrm{S}}$ & 40 & - & $24)$ \\
$M_{\mathrm{C}}$ & $1.2 \times 10^{-2}$ & $\mathrm{~kg} \mathrm{~mol}^{-1}$ & - \\
$M_{\mathrm{S}}$ & $3.2 \times 10^{-2}$ & $\mathrm{~kg} \mathrm{~mol}^{-1}$ & - \\
\hline
\end{tabular}
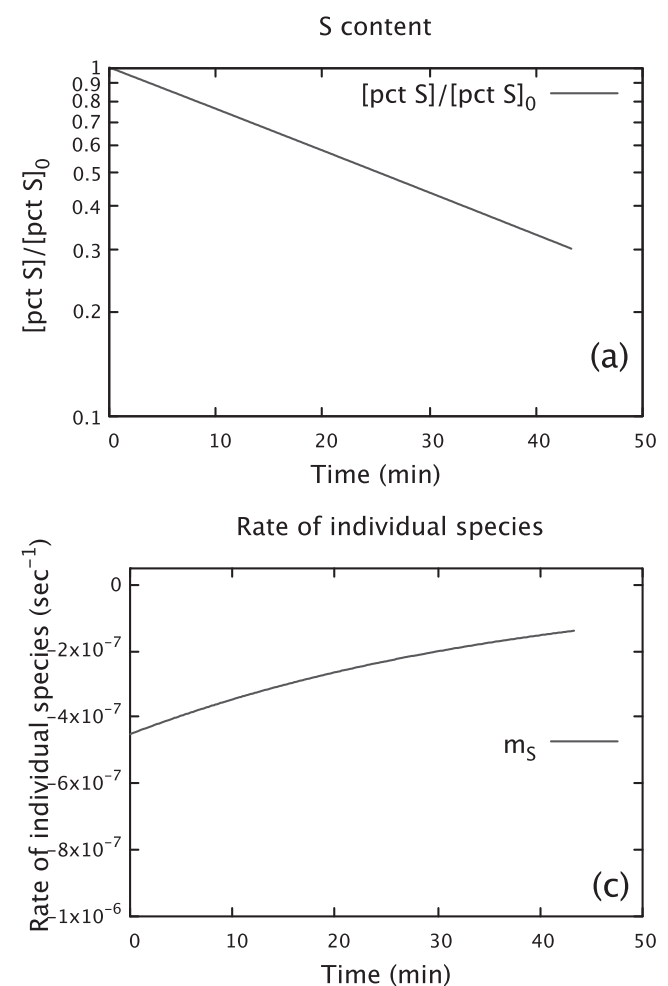

\section{Discussions}

Using the model Eqs. ((8) to (11)), evaporation of $\mathrm{S}$ in liquid $\mathrm{Fe}-\mathrm{C}-\mathrm{S}$ alloys of various compositions were calculated at $1873 \mathrm{~K}$. [pct $\mathrm{C}]_{0}=0$ and 5 , and [pct S $]_{0}=0.001$ and 0.1 were chosen as example. Figures 5 to 8 show the calculated results of (a) [pct S]/[pct S $]_{0}$, (b) $m_{\mathrm{S}}, k_{\mathrm{S}}, k_{\mathrm{CS}}$, and $k_{\mathrm{CS}_{2}}$, (c) evaporation rate of individual species $(\mathrm{S}(\mathrm{g}), \mathrm{CS}(\mathrm{g})$, and $\mathrm{CS}_{2}(\mathrm{~g})$ ), and (d) proportion of evaporating species, from Fe-0.001S, Fe-0.1S, Fe-4.5C-0.001S, and Fe-4.5C-0.1S, respectively. It is believed that each figure shows meaningful information how $\mathrm{S}$ evaporates either in Fe-S alloy or Fe-C-S alloy. In Figs. 5 and $\mathbf{6}$, since $[\text { pct } \mathrm{C}]_{0}=0, \mathrm{~S}(\mathrm{~g})$ is the only evaporating species. Increasing [pct $\mathrm{S}]_{0}$ increases evaporation rate of $\mathrm{S}$, but apparent rate constant $m_{\mathrm{S}}$ decreased slightly due to surface adsorption effect. Figures 7 and 8 show the evaporation of $\mathrm{S}$ when $[\text { pct } \mathrm{C}]_{0}=4.5$. First, decrease of [pct $\mathrm{S}$ ] was significantly accelerated compared to that shown in Figs. 5 and 6. Interesting point is that $\mathrm{S}(\mathrm{g})$ is a major evaporating species for low $\mathrm{S}$ containing sample (Fig. 7(d)), while $\mathrm{CS}_{2}(\mathrm{~g})$ is a major evaporating species for high S containing sample (Fig. 8(d)). Also, as the evaporation proceeds, [pct S] gradually decreases and proportion of $\mathrm{CS}(\mathrm{g})$ increases to non-negligible level. As also shown in Fig. 2(b) for the case of [pct $\mathrm{S}]_{0}=0.068$ and $\mathrm{C}$ saturation condition, proportion of $\mathrm{CS}(\mathrm{g})$ becomes almost as high as that of $\mathrm{CS}_{2}(\mathrm{~g})$ at later stage of evaporation.

Evaporation of $\mathrm{S}$ in $\mathrm{C}$ saturated liquid $\mathrm{Fe}-\mathrm{C}-\mathrm{S}$ alloys investigated by Jung et al. ${ }^{7)}$ assumed that $\mathrm{CS}_{2}(\mathrm{~g})$ was the only evaporating species. From the Figs. 2(b) and 8(d), it can be seen that $\mathrm{CS}_{2}(\mathrm{~g})$ is indeed a major evaporating species as long as [pet $\mathrm{S}$ ] is not too low. This lends strong support to the assumption made by Jung et al. ${ }^{7)}$ Therefore, it
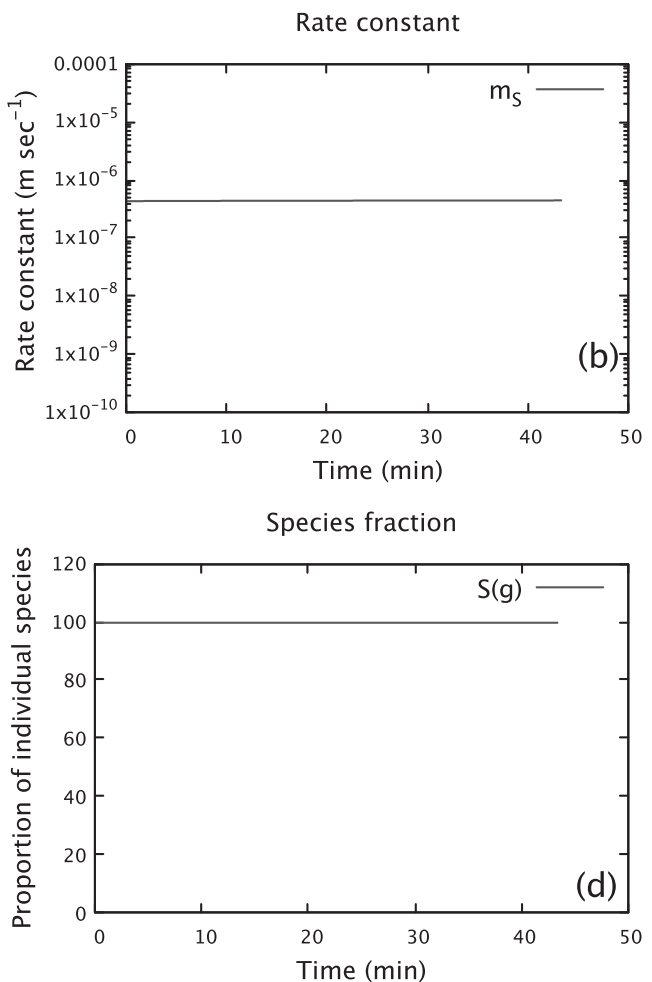

Fig. 5. Various information obtained from the present kinetic model for Fe-0.001S alloy at $1873 \mathrm{~K}$ : (a) normalized S content $[$ pct $\mathrm{S}] /[\text { pct } \mathrm{S}]_{0}$, (b) overall rate constant $m_{\mathrm{S}}$, (c) individual evaporation rate of $\mathrm{S}(\mathrm{g})$, and (d) proportion of evaporating species. 

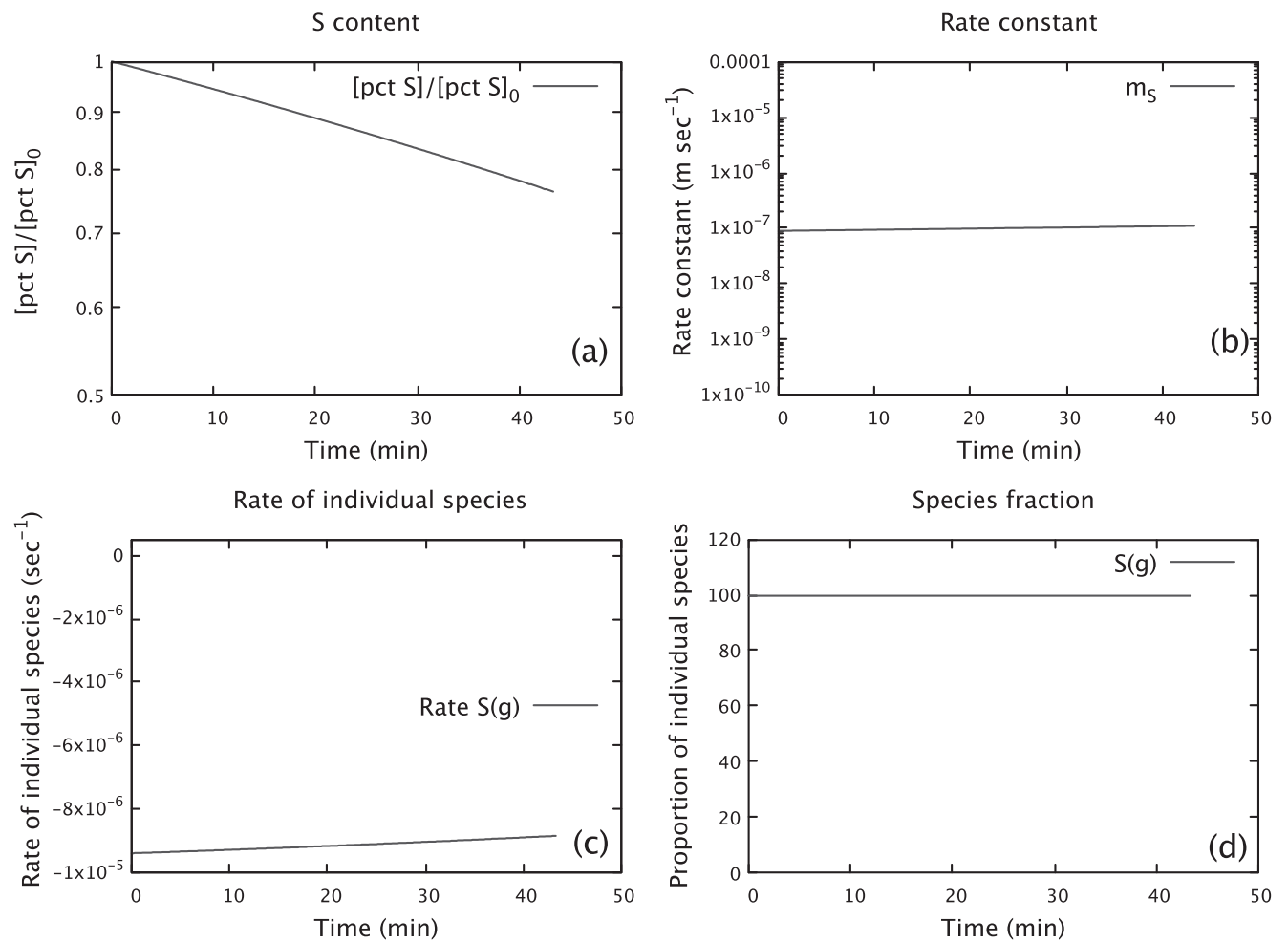

Fig. 6. Various information obtained from the present kinetic model for Fe-0.1S alloy at $1873 \mathrm{~K}$ : (a) normalized S content $[\mathrm{pct} \mathrm{S}] /[\mathrm{pct} \mathrm{S}]_{0}$, (b) overall rate constant $m_{\mathrm{S}}$, (c) individual evaporation rate of $\mathrm{S}(\mathrm{g})$, and (d) proportion of evaporating species.
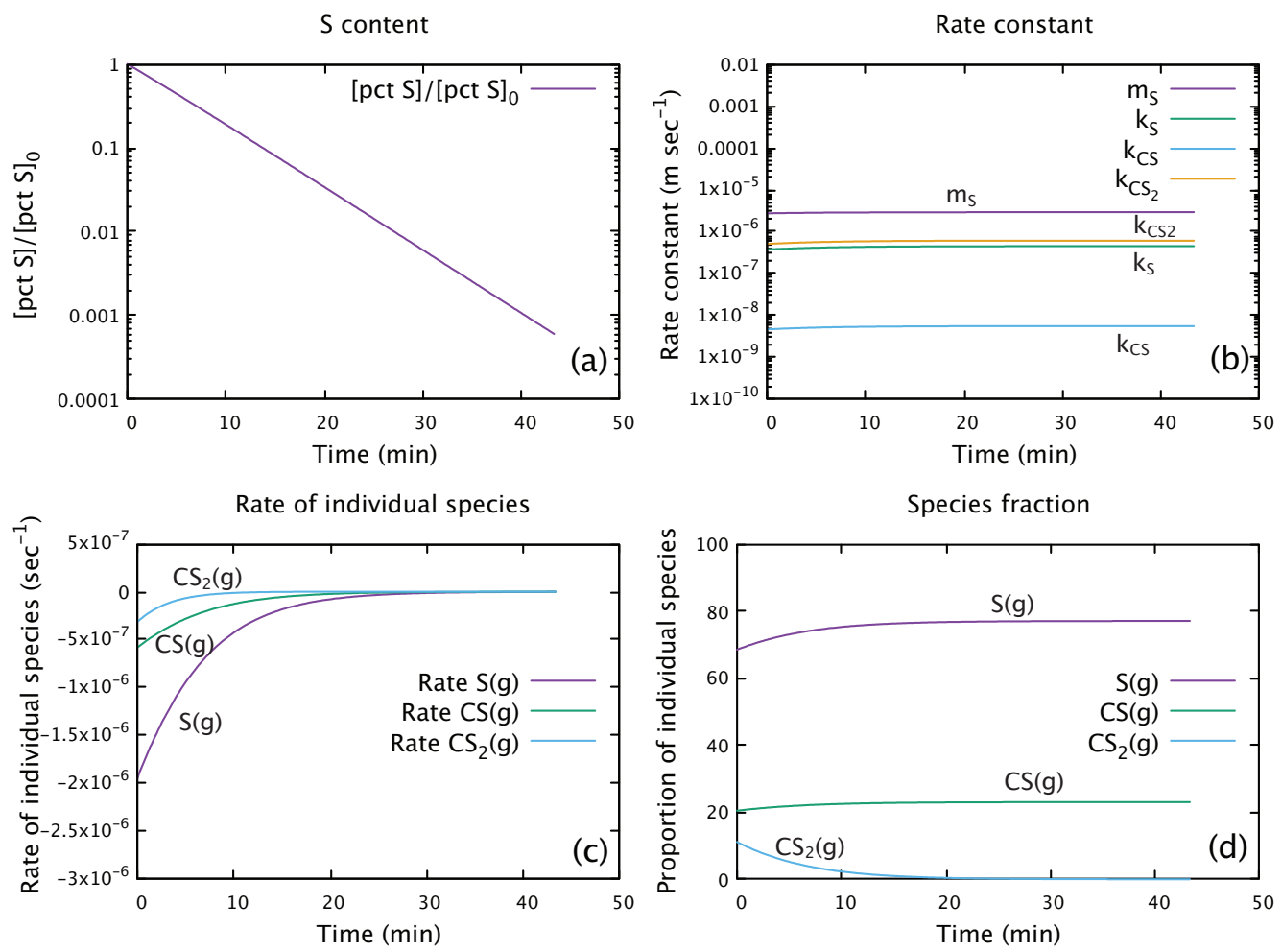

Fig. 7. Various information obtained from the present kinetic model for Fe-5C-0.001S alloy at $1873 \mathrm{~K}$ : (a) normalized $\mathrm{S}$ content $[\mathrm{pct} \mathrm{S}] /[\mathrm{pct} \mathrm{S}]_{0}$, (b) overall rate constant $m_{\mathrm{S}}$, and apparent rate constant of individual species $k_{\mathrm{S}}, k_{\mathrm{CS}}$, and $k_{\mathrm{CS}_{2}}$, (c) individual evaporation rate of $\mathrm{S}(\mathrm{g}), \mathrm{CS}(\mathrm{g})$, and $\mathrm{CS}_{2}(\mathrm{~g})$, and (d) proportion of evaporating species. (Online version in color.)

is concluded that consideration of carbosulfide evaporation in $\mathrm{Fe}-\mathrm{C}-\mathrm{S}$ alloys is inevitable.

From the results shows in Figs. 5(b), 6(b), 7(b), and 8(b), it can be seen that the overall apparent rate constant $m_{\mathrm{S}}$ is virtually constant during the evaporation. This is due to the fact that decreasing [pct S] increases $k_{\mathrm{S}}, k_{\mathrm{CS}}$, and $k_{\mathrm{CS}_{2}}$, and this might keep the $m_{\mathrm{S}}$ nearly constant.

The present kinetic model employed only three parameters 

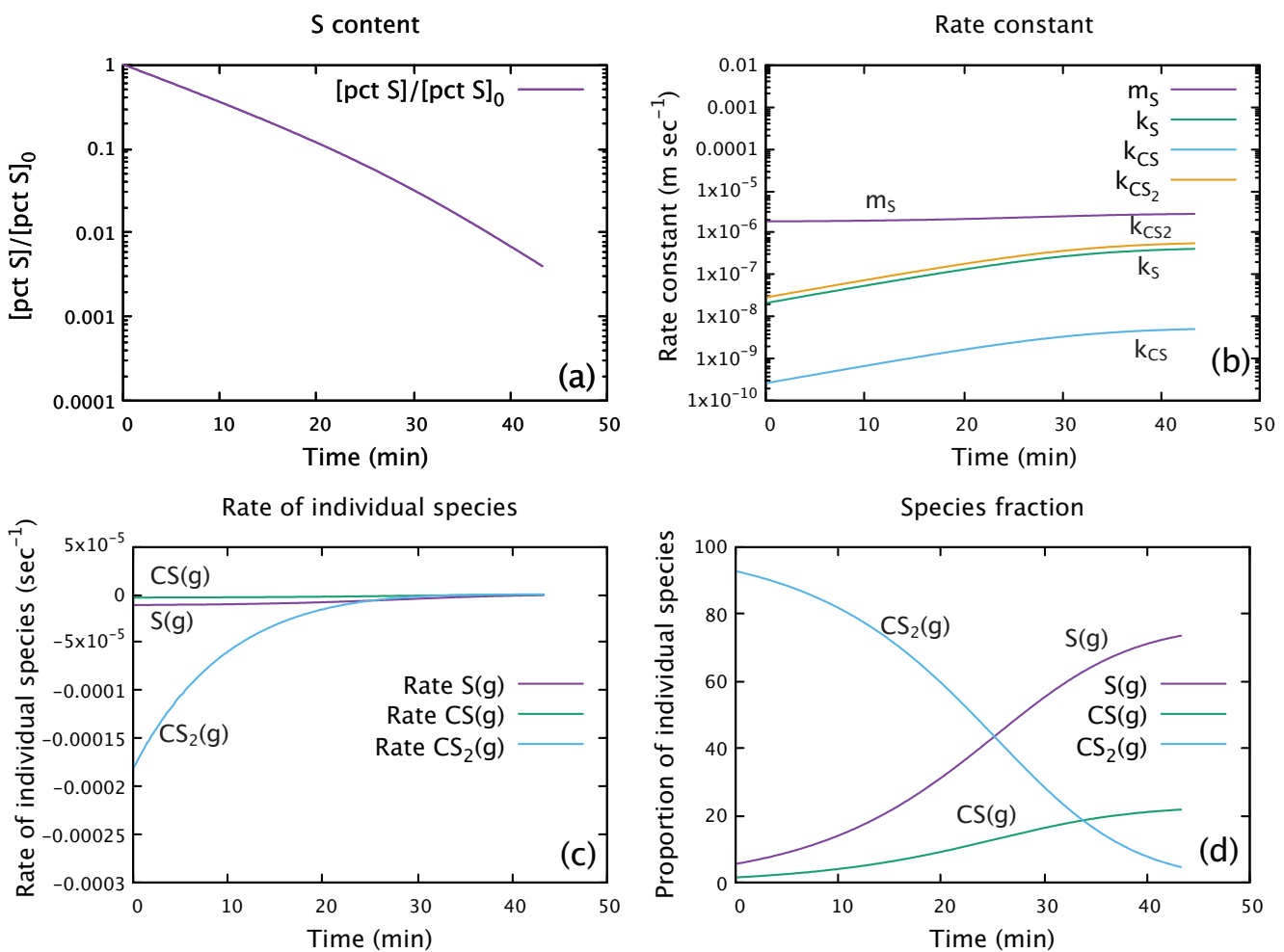

Fig. 8. Various information obtained from the present kinetic model for Fe-5C-0.1S alloy at $1873 \mathrm{~K}$ : (a) normalized S content $[\mathrm{pct} \mathrm{S}] /[\mathrm{pct} \mathrm{S}]_{0}$, (b) overall rate constant $m_{\mathrm{S}}$, and apparent rate constant of individual species $k_{\mathrm{S}}, k_{\mathrm{CS}}$, and $k_{\mathrm{CS}_{2}}$, (c) individual evaporation rate of $\mathrm{S}(\mathrm{g}), \mathrm{CS}(\mathrm{g})$, and $\mathrm{CS}_{2}(\mathrm{~g})$, and (d) proportion of evaporating species. (Online version in color.)

(chemical reaction rate constants $\left(k_{\mathrm{S}}^{\mathrm{R}}, k_{\mathrm{CS}}^{\mathrm{R}}\right.$, and $\left.k_{\mathrm{CS}_{2}}^{\mathrm{R}}\right)$ which were obtained in order to reproduce available experimental data. Employed thermodynamic data (interaction parameters: $e_{\mathrm{S}}^{\mathrm{C}}$ and $r_{\mathrm{S}}^{\mathrm{C}}$ ) were consistent with all available thermodynamic and phase equilibrium data. ${ }^{17)}$ For the present kinetic model, applicable composition range of $\mathrm{C}$ is from 0 to its saturation (approximately 5 mass pct.), and that of $\mathrm{S}$ is from 0 to 0.5 mass pet, which were confirmed in the present study.

The present kinetic model is very important to calculate evaporation rate of $\mathrm{Cu}$ and $\mathrm{Sn}$ from liquid iron containing $\mathrm{Cu}, \mathrm{Sn}, \mathrm{C}$, and $\mathrm{S}$ which may be obtained by melting ferrous scrap with hot metal. Cooperative evaporation phenomena of $\mathrm{Cu}, \mathrm{Sn}$, and $\mathrm{S}$ were already well described by Jung et al. ${ }^{9)}$

\section{Conclusions}

A kinetic analysis for the evaporation of $\mathrm{S}$ from liquid $\mathrm{Fe}-\mathrm{C}-\mathrm{S}$ alloy was presented. In $\mathrm{C}$ containing melt, importance of carbosulfide evaporation is shown. Increasing evaporation rate of $\mathrm{S}$ by $\mathrm{C}$ was attributed to the fact that 1) $\mathrm{C}$ increases activity coefficient of $\mathrm{S}$, and 2) $\mathrm{C}$ forms volatile carbosulfide species. The latter is consistent with the proposal of Belton et al. ${ }^{13)}$ Contrary to the approach by $\mathrm{Wu}$ et al., ${ }^{10)}$ thermodynamically consistent interaction parameters were used in the present study which were taken from the present authors' CALPHAD type thermodynamic modeling of $\mathrm{Fe}-\mathrm{C}-\mathrm{S}$ system. ${ }^{17)}$ The present kinetic model could explain the role of $\mathrm{C}$ on the evaporation of $\mathrm{S}$ reasonably. It can be further used in the calculation of evaporation rate of $\mathrm{Cu}$ and $\mathrm{Sn}$ from liquid iron containing $\mathrm{C}$ and $\mathrm{S}$, where evaporation rates of $\mathrm{Cu}$ and $\mathrm{Sn}$ are significantly dependent on the evaporation of $\mathrm{S}$.

\section{REFERENCES}

1) R. J. Fruehan and E. T. Turkdogan: Metall. Trans., 2 (1971), 895.

2) R. M. McKechnie: Electric Furance Steel Proc., Vol. 12, AIME, New York, (1954), 38.

3) J. Keverian and H. F. Taylor: Trans. AFS, 65 (1957), 212.

4) G. A. Garnyk and A. M. Samarin: Akd. Nauk. SSSR, Otdel. Tekin Nauk., 5 (1957), 77.

5) S.-H. Jung, Y.-B. Kang, J.-D. Seo, J.-K. Park and J. Choi: Metall. Mater. Trans. B, 46B (2015), 250.

6) S.-H. Jung, Y.-B. Kang, J.-D. Seo, J.-K. Park and J. Choi: Metall. Mater. Trans. B, 46B (2015), 259.

7) S.-H. Jung, Y.-B. Kang, J.-D. Seo, J.-K. Park and J. Choi: Metall. Mater. Trans. B, 46B (2015), 267.

8) S.-H. Jung and Y.-B. Kang: Metall. Mater. Trans. B, 47B (2016), 2164.

9) S.-H. Jung and Y.-B. Kang: Metall. Mater. Trans. B, 47B (2016), 2564.

10) P. Wu, Y. Yang, M. Barati and A. McLean: ISIJ Int., 55 (2015), 717.

11) V. D. Sehgal and A. Mitchell: J. Iron Steel Inst., 202 (1964), 216.

12) J. P. Morris and R. C. Buckl: Trans. AIME, 188 (1950), 317.

13) G. R. Belton, R. J. Fruehan and E. T. Turkdogan: Metall. Trans., 3 (1972), 596.

14) J. F. Elliott and M. Gleiser: Thermochemistry for Steelmaking, Vol. 1, Addison-Wesley Pub. Co., Reading, MA, (1960), 266.

15) I. Langmuir: J. Am. Chem. Soc., 40 (1918), 1361.

16) G. K. Sigworth and J. F. Elliott: Met. Sci., 8 (1974), 298

17) F. Tafwidli and Y.-B. Kang: ISIJ Int., 57 (2017), 782.

18) E. Kato and Y. Fukube: Tetsu-to-Hagané, 55 (1969), 445.

19) R. Ohno: Sci. Rep. Res. Inst. Tohoku University, Ser. A, Phys. Chem. Metall., 12 (1960), 353

20) M. Homma and R. Ohno: Sci. Rep. Res. Inst. Tohoku University, Ser. A, Phys. Chem. Metall., 16 (1964), 139.

21) C. W. Bale, E. Belisle, P. Chartrand, S. A. Decterov, G. Eriksson, K. Hack, I.-H. Jung, Y.-B. Kang, J. Melancon, A. D. Pelton, C. Robelin and S. Petersen: Calphad, 33 (2009), 295.

22) C. W. Bale, E. Bélisle, P. Chartrand, S. A. Decterov, G. Eriksson, A. E. Gheribi, K. Hack, I.-H. Jung, Y.-B. Kang, J. Melançon, A. D. Pelton, S. Petersen, C. Robelin, J. Sangster, P. Spencer and M.-A. Van Ende: Calphad, 54 (2016), 35.

23) I. Jimbo and A. Cramb: Metall. Trans. B, 24B (1993), 5.

24) K. Sekino, T. Nagasaka and R. J. Fruehan: ISIJ Int., 40 (2000), 315.

25) K. Harashima, S. Mizoguchi, M. Matsuo and A. Kiyose: ISIJ Int., 32 (1992), 111.

26) T. Nagasaka and R. J. Fruehan: Metall. Mater. Trans. B, 25B (1994), 245. 